\title{
Agua y tiempo en el arte
}

\author{
Juan Pando Despierto *
}

Elemento básico de la división simbólica del mundo antiguo, el agua sigue siéndolo en la modernidad, y con una autoridad indiscutible, a la que su propia potencia - y su rareza esencial tratándose de agua dulce-. proporcionan un vigor estético y una fuerza geoestratégica planetarias.

El arte hizo siempre del agua un factor de meditación y de representación, de concreción de los sueños del hombre. Su ductilidad plástica. propia para todos los marcos, todas las facturas, la hizo servir también como vehículo expresivo de todas las culturas. Unida a la eclosión misma de la vida, el agua es simil igualmente de tiempo: mientras ella exista. aquél será "comprensible», esto es, habitado por la inteligencia humana.

\section{EVOLUCIÓN CONCEPTUAL Y PICTÓRICA}

Por ceñirnos a una datación histórica concreta, que no pretende ser totalitaria ni tampoco inaugural en la "presentación" artística del agua. en el arte egipcio se encuentran bellísimos ejemplos de esa fascinación secular del hombre hacia el elemento al que reconoce como sustento de la vida. Así ocurre en las pinturas halladas sobre una pared en la tumba de Chnemhotep, un dignatario del Imperio Medio, sepultado cerca de beniHassán (ca. 1900 AJC). Los cazadores de Chnemhotep aparecen de perfil, figuras gráciles $y$, sin embargo, poderosas que se deslizan por una superficie tersa pero no inocente (fig. 1). Para los que tienden a la precipitación analítica, estas escenas carecen de utensión"e, incluso, de credibilidad, juicios ambos erróneos. De ahí que una mente ágil como Gombrich advierta taxativamente:

* Dpto. H. ${ }^{\text {a }}$ del Arte. UNED. 


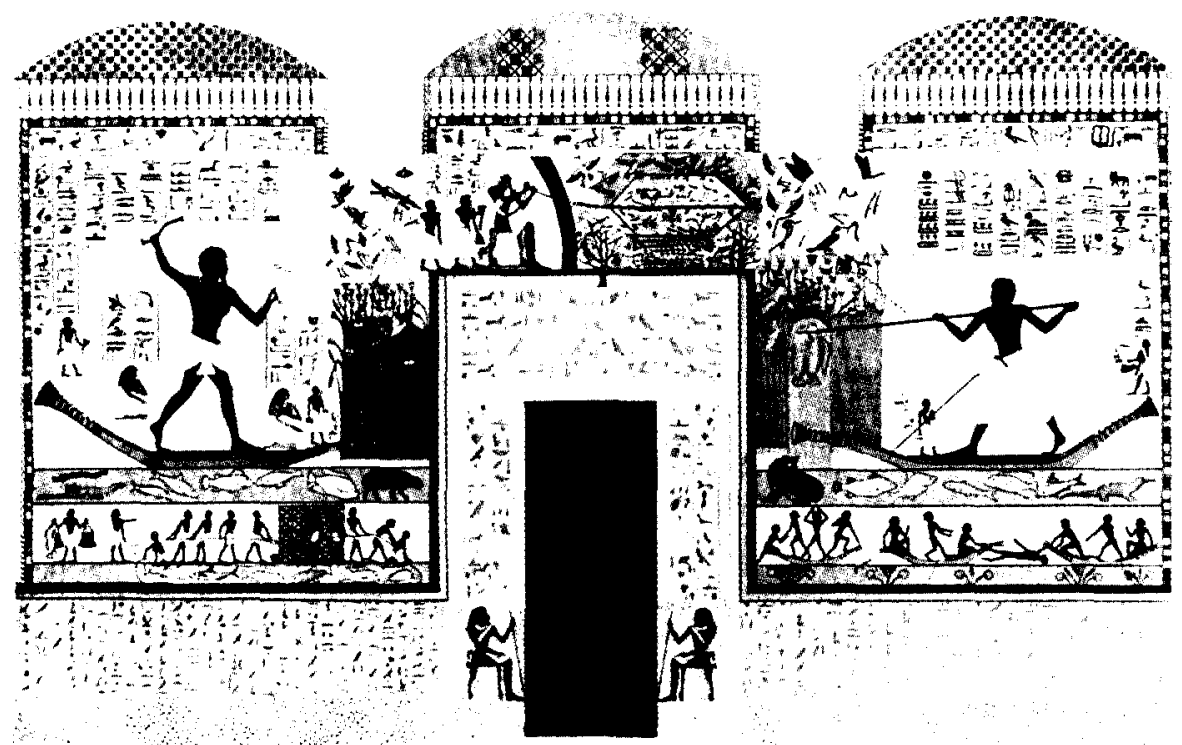

Fig. 1. "Pinturas sobre una pared de la tumba de Chnemhotep". Beni-Hassan (Egipto) (Ca. $1900 \mathrm{AJC}$ ).

"Creo que una vez acostumbrados a contemplar esas pinturas egipcias nos preocupan tan poco sus falțas de verosimilitud como la ausencia del color en las fotografías" '.

El arte oriental, especialmente el chino, haría un uso sugestivo, "distinto", del agua en la concepción del paisaje o en su ensambladura con los factores atmosféricos. Un impresionante ejemplo de esto último es la pintura sobre seda de Kao-Ko-kung, Paisaje después de la lluvia (ca. 1250-1300), en el que las montañas y los árboles emergen de una condensación colosalista de volúmenes nubosos luego del paso de la borrasca. Los viejos límites han sido trastocados, con ser esencialmente los mismos. Todo cobra una nueva grandiosidad, y aunque la lluvia es sólo "coincidencia", el paisaje superviviente a su directa intervención es exclusiva obra suya (fig. 2).

En el arte occidental, tan poco dado a la exaltación de los símbolos que no hubieran sido previamente divinizados por los intereses políticos 


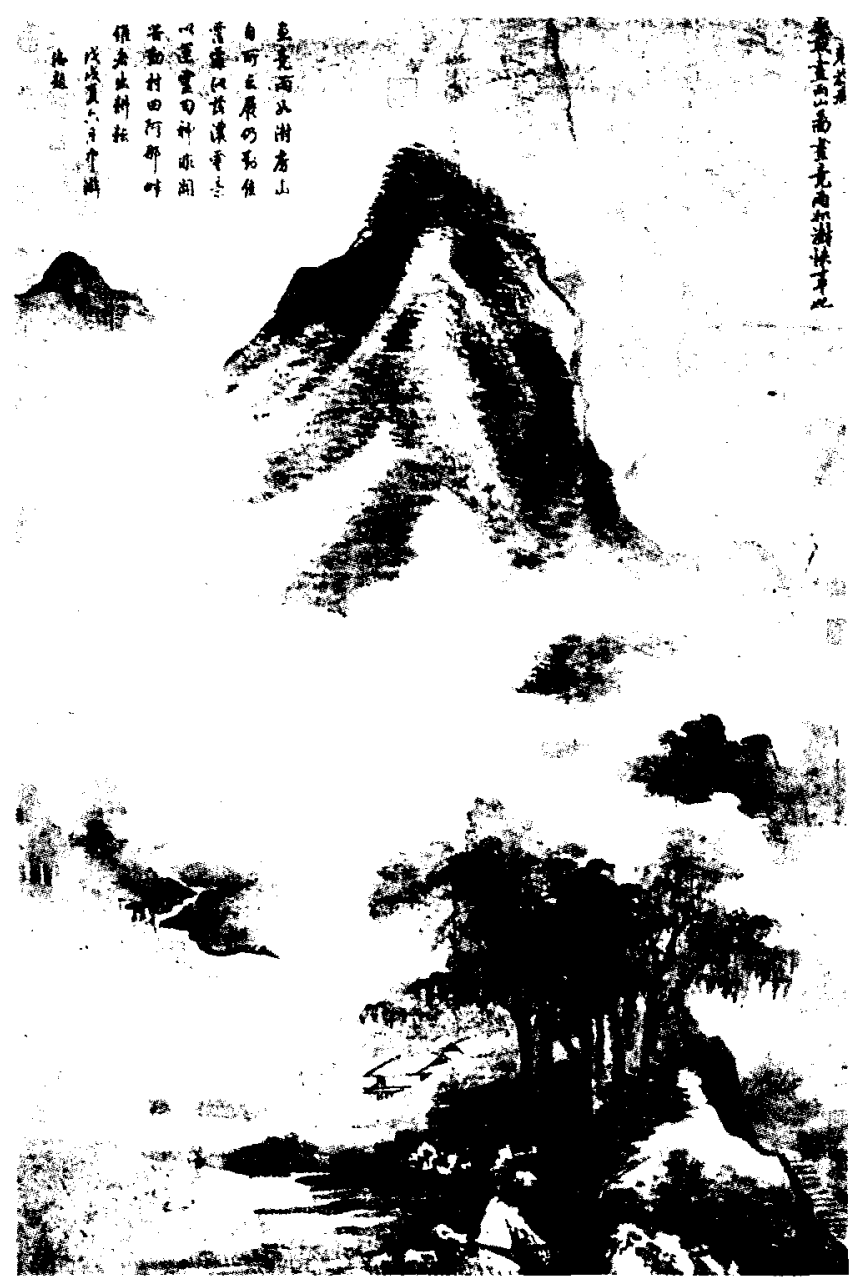

Fig. 2. Paisaje después de la lluvia (Ca. 1250-1300). Kao K'oRung.

- Ios mandamientos religiosos, el agua padecía una "ignorancia" de sus posibilidades explicativas. De esta forma el conocido Tapiz de Bayeux (ca. 1080), que relata, en su más estricta linealidad, la invasión normanda de los países sajones en Britania, utiliza el agua como un simple "carril" por donde circulan, con bélica facilidad, no sólo las temibles naves de características vikingas, sino toda una filosofía elemental de la furia para lo que no son necesarias otras naturalezas adyacentes (fig. 3). 


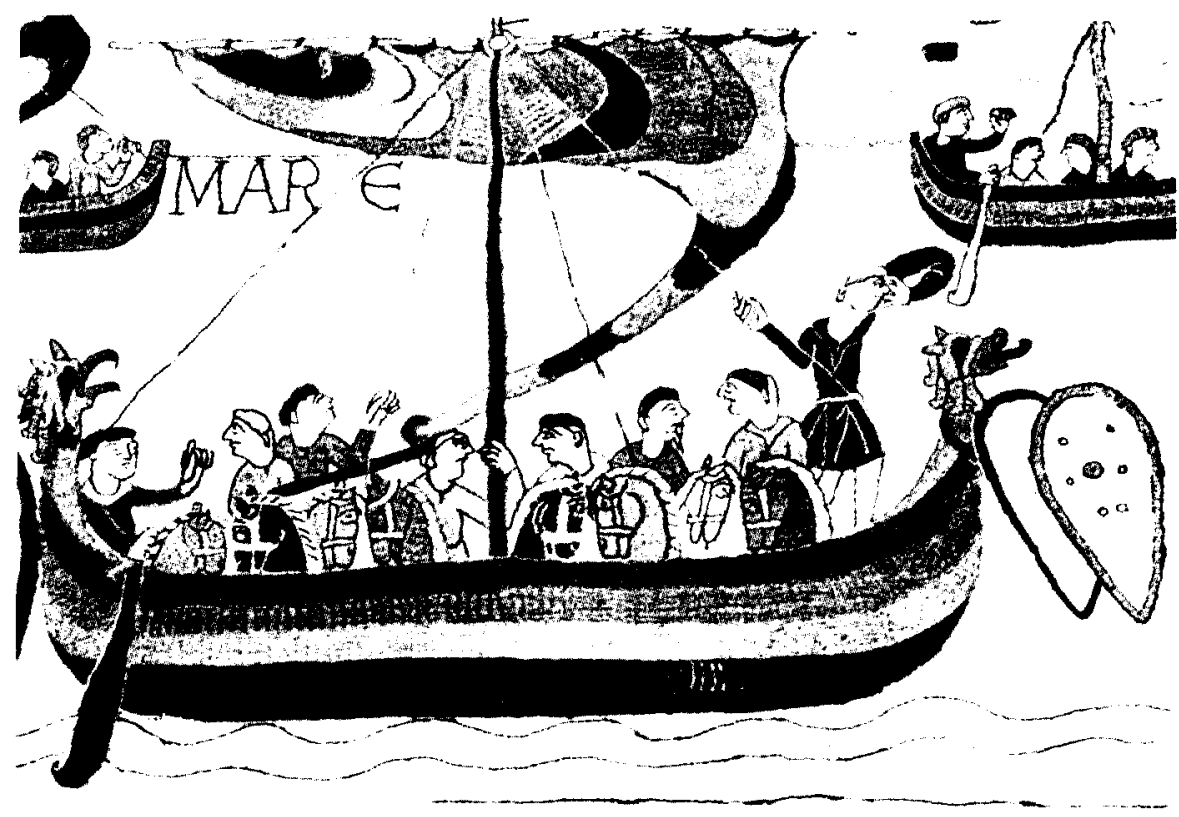

Fig. 3. "Tapiz de Bayeux" (Ca. 1080).

El agua, en el arte medieval de Occidente, dificilmente podia separarse del rígido marco impuesto por la cristianización de los elementos naturales. Tan asfixiante acoso convertía a éstos en símbolos virtualmente paganos. Ya en el Quattrocento, el nuevo cambio de mentalidad estética que antecede a la normativa renacentista, se producen discretas liberaciones del agua en el arte, dotándola de una progresiva autonomía. Pero tanto en la metodología de los grandes maestros de la época (Durero, Rafael), como en el conocimiento espiritual que del agua entonces se tiene, impiden mayores osadias. Los estilistas de la cultura posterior (Rubens, Ribera, Rembrandt) no pretenderán tampoco hacer alardes simbolistas con el agua, y en el conjunto del fenómeno barroco dicho elemento no pasó de ser un "segundo sujeto", subordinado enteramente a la consecución de los fastos de la religión, la política o la milicia, y a los que dotaba del vestuario pertinente.

Obviamente, había excepciones, especialmente en la paisajística, con obras de Simón de Vlieger, Jan van Goyen, y posteriormente, con autores más «atrevidos»: Claudio de Lorena, Jacob van Ruisdael o Francesco Guardi. Pero en todas estas creaciones el agua seguía manteniendo una función secundaria a los grandes diseños del interés nacional o dinástico 
y a las inercias ornamentales de una sociedad interesada sólo ante una belleza "comoda" de la realidad.

En esencia, y con todos los matices que se quiera, el agua no pasaba de ejercer una tarea meramente decorativa en las artes prerrománticas Parecia como si las técnicas artísticas. más que el pensamiento del artista. fuesen incapaces de reflejar la categoria bidimensional del agua y el tiempo.

Con la Escuela de Barbizon y los logros de John Constable, las limitaciones hacia el agua disminuyeron notoriamente, hasta que la eclosión de esos grandes intervencionistas sobre las sensaciones que fueron Géricault, Delacroix. Friedrich y Turner literalmente desarticuló esa prisión conceptual del arte en la que estaban encerrados el agua y el tiempo.

Con La balsa de la Medusa, de 1818-19. Théodore Géricualt (1791. 1824) sitúa el agua como factor desasosegante y aniquilador, pese a que el retrato colectivo de los náufragos ocupe prácticamente todo el lienzo, lo que no empece para que se comprenda perfectamente quien es el "sujeto principal», el argumento que guía la dramática historia (fig. 4).

Eugène Delacroix (1798-1863). con La barca de Dante, de 1822, intro-

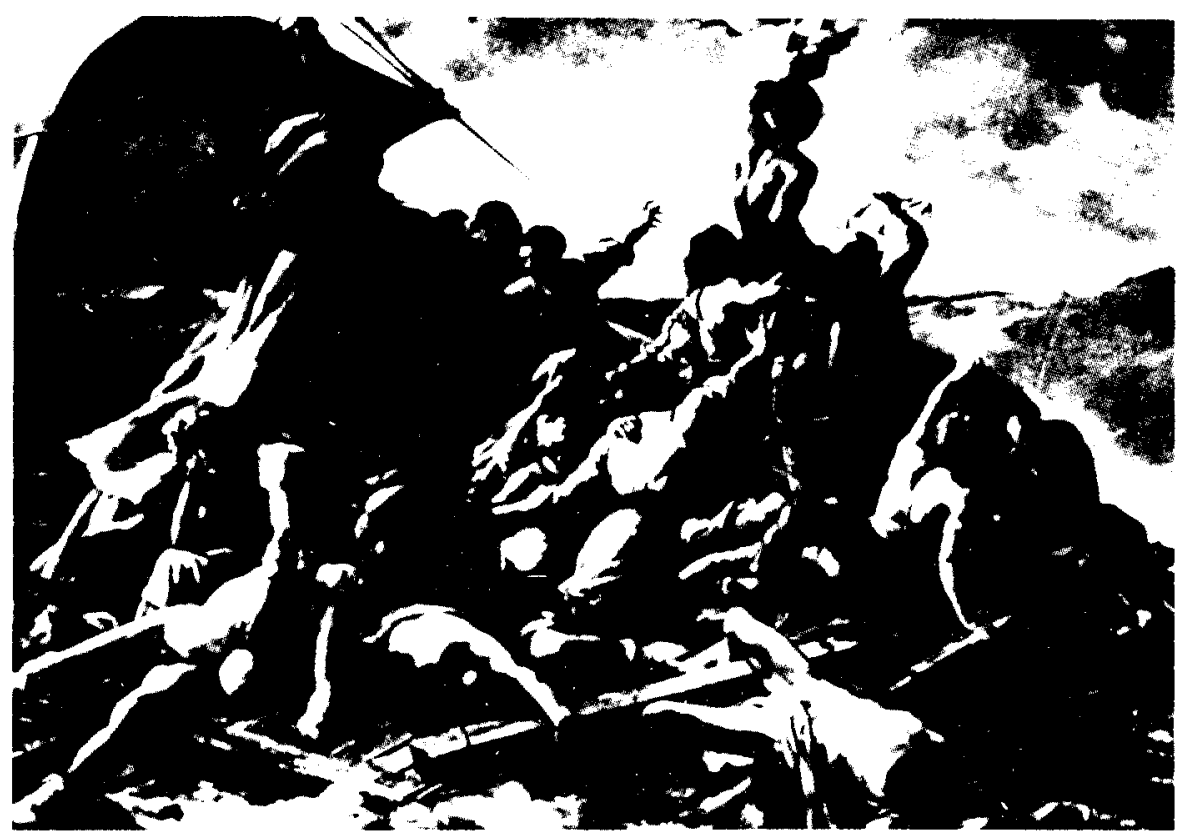

Fig. 4. "La bolsa de la Medusa". Theodore Gericualt (1818-19). 


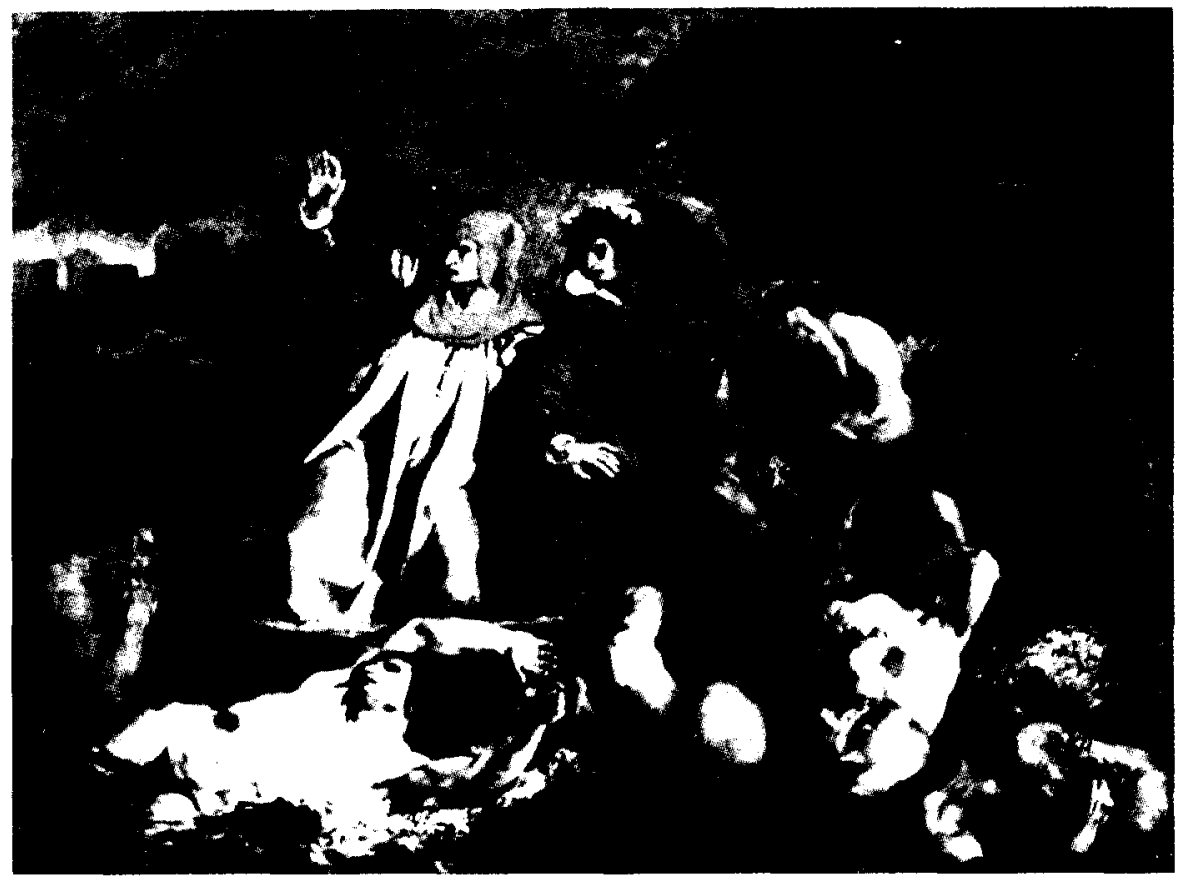

Fig. 5. "La barca de Doute». Eugene Delacroix (1822).

duce el agua en un espacio temible de dimensiones abismales, donde todo es inestable y todo supone una amenaza de muerte. El hombre oscila en su precariedad secular, y el agua ha dejado de ser "un espejo amable». De ella surgen troncos humanos martirizados, rostros dominados por el espanto, todo el fragor universal de los gritos históricos del pecado (fig. 5).

El régimen de Carlos $X$, tal vez sugestionado por sus propias culpas sociopolíticas compró la pintura, y Adolphe Thiers, que entonces hacia sus primeras armas conceptistas, no dudó en afirmar: "No creo equivocarme, el señor Delacroix ha recibido el genio". El antirrevolucionario rendía pleitesia a las revoluciones aparentemente inocuas, es decir, "artísticas".

Más al este, en las profundidades germánicas, brotaba una potente simbolización que lideraría Caspar David Friedrich (1774-1840). Su lienzo El naufragio del "Esperanza», de 1821, que representa el aplastamiento por los hielos de la nave de William Parry en su fallida expedición el Ártico, elevaba el agua y el tiempo a una nueva jerarquización, donde la realidad 
se subsumia en una fascinación por lo real, y en la que el engaño estético amortiguaba la brutalidad de los hechos.

El romanticismo generó siempre importantes hendeduras por donde se deslizaron las categorias de la realidad hacia una sima sin fondo. Del mismo modo, lo que yacía en esa profundidad cavernosa se presentaba como evidente, indiscutible, "real». Estas acciones llevaron a definiciones como las estructuradas por Adorno:

"El arte fantástico, tanto el romántico como lo que de él hay en el manierismo y en el barroco, nos presentan lo no existente como existente. Las creaciones imaginarias son modificaciones de lo empíricamente presente. La consecuencia es presentarnos algo que no es empírico como si lo fuera" ${ }^{2}$

No obstante, existían singularidades formales y materiales manifiestas, de las que es un ejemplo la obra de Friedrich. Que un barco quede aprisionado por los hielos era un hecho relativamente frecuente en el romanticismo, época donde las mareas descubridoras hacia los polos se producían con cíclico empeño. De esta forma, lo anormal se transformaba en desafiante normalidad.

En el lienzo de Friedrich, el buque no ha desaparecido, sino que se ha fundido con los montículos helados y la historia. La aventura del hombre queda asi inmortalizada, de la misma manera que su efímera vanidad queda destruida entre témpanos y silencios. Una sorprendente estratificación de ángulos y vértices conmemora el final de una utopía. La tumba del Esperanza antecede, geométricamente, el diseño conceptual de Feininger, con sus fugaces veleros del periodo de entreguerras. Es una catedral de conceptos erigida en honor a la inmovilidad, pero esto, claro está, es una mera apariencia, y Friedrich faltaría a su dinámica romántica -y a la lógica de la física de los cuerpos- si no hubiese creído necesario representarlo de esa forma.

La movilidad reside en el interior, donde las fuerzas geológicas trituran el casco y las temeridades de los hombres que lo guiaron hacia su final. La sorpresa del hombre ante la naturaleza se yergue en una mueca de estupor herido. El buque y quienes lo tripularon forman parte de un túmulo de las presunciones, enclavado en una meseta interminable de la lógica en la cual se desenvuelve con sereno despotismo el tiempo.

La batalla, como todas las luchas titánicas, se desarrolla simultánea-

Adonno, Theodor, W. Teoria Estética. Versión castellana de Fernando Rieza, revisada por Francisco Pérez Gutiérrez. Madrid 1980, Tauruus, 479 páginas, vid. pág. 34. 


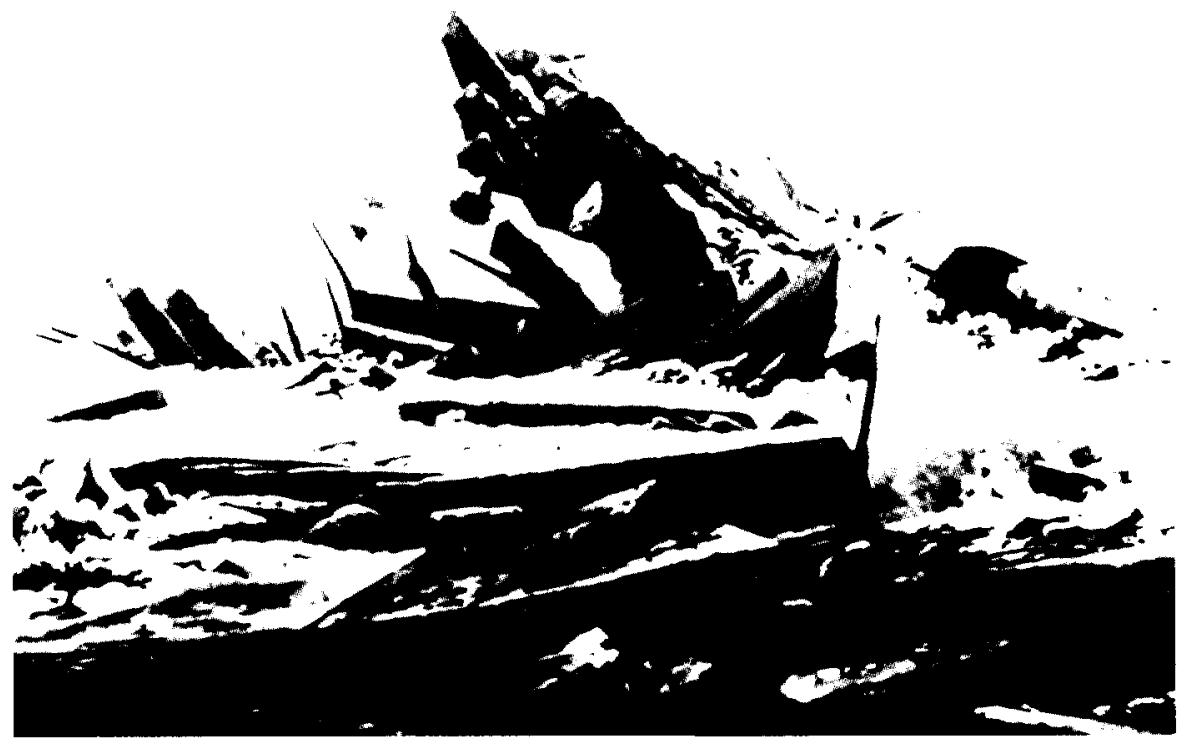

Fig. 6. "El nautragio del "Esperanza"”. Gaspar David Friedrich (1821).

mente de forma descubierta y oculta. $Y$ en la superficie apenas se vislumbra el combate epopéyico que tiene lugar debajo de esas pirámides heladas, de las que cuelgan los despojos de un navío, es decir, de una ilusión romántica, un sueño humanizado.

De ahí que Janson, tras preguntarse cómo habría representado Turner este episodio, y colegir que la inmovilidad que fascinó a Friedrich hubiese sido "demasiado estática" para el gran pintor británico, deduce que el autor germano se sintió, en cambio, atraído por esa inactividad, y estima que Friedrich "ha plasmado los témpanos de hielo amontonados como una especie de monumento megalítico a la derrota humana levantado por la propia naturaleza" ${ }^{3}$. Exactamente fue ese su sentido.

Joseph Mallard William Turner (1775-1851), es el pintor de las emociones geoatmosféricas, que nunca más tuvieron un intérprete tan atrevido 
y consecuente a la vez. Con Turner, rara es la visión que no supone una estremecedora sensación de incertidumbre. Para él, la vida es una "tormenta", y pocos artistas habrán sabido representar así el romanticismo: un combate de masas, de luces, de perspectivas y emociones, un temeroso vacuum postromano del que suele derivarse una pacificación luminosa de las formas combatientes, como si todos los materiales y conceptos hubiesen quedado agotados tras semejante pelea "sin condiciones"

Pero Turner no es pesimista, todo to contrario: sus enfrentamientos con los elementos no concluyen en masivas tragedias o catástrofes personalizadas. El hombre no muere en la obra de Turner, tan sólo lucha por vivir, lo que no deja de ser un realismo antirromántico. Su Vapor en la ventisca, de 1842, resume ese vértigo del que, ciertamente, puede deducirse un naufragio, pero también una apertura posterior hacia momentos menos angustiosos (fig. 7).

El agua y el tiempo son dos pasiones turnerianas en las que todo fluye y todo permanece. Es el hombre (el barco) quien se limita a deslizarse, "levemente", por entre este espectáculo magnífico de lo natural convertido

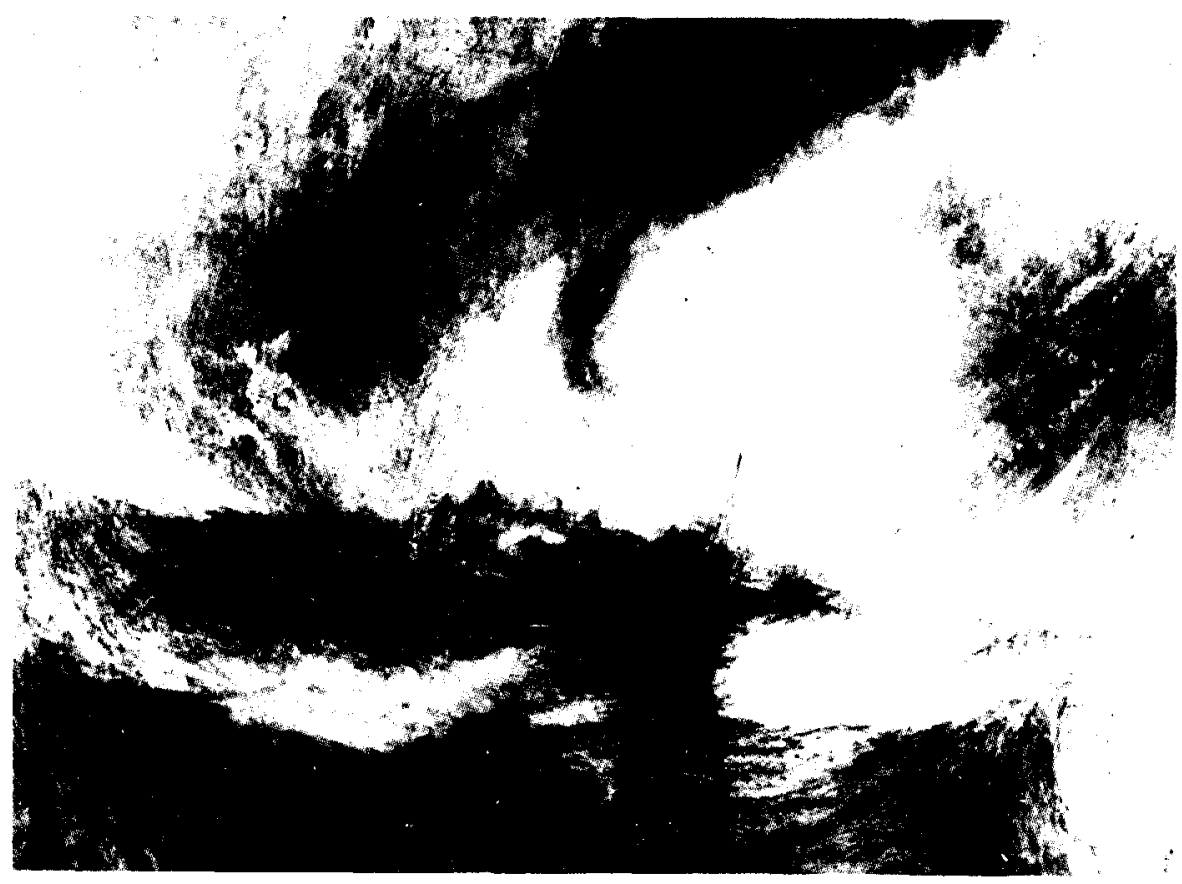

Fig. 7. "Vapor en la ventisca". Joseph Mallard Willam Turner (1842) 
en factor extraordinario y mutante, pues puede conducir tanto a la salvación como a la hecatombe.

Con el impresionismo, el agua se convirtió en una "belleza relativa». que el expresionismo situaria en otros niveles. Así, por ejemplo, Ferdinand Hodler (1853-1918), va a transformar una de las señales dinamizantes de la poética universal en algo simplemente tranquilizador: el agua convertida en un "cartel». Se terminaron las angustias románticas, y de las justas turnerianas entre agua, cielo, tierra y tiempo, tan sólo subyace una placidez turística. Todo es hermoso, $y$ "todo es felicidad".

Como dice Janson, con este tipo de obra "se puso de manifiesto, sobre todo, un problema: el del conflicto entre esquema y solidez" ". El arte se ha industrializado, las sociedades siguen teniendo el mismo miedo a reconocerse, pero los dogmas de la moral costumbrista y el derecho natural se confunden, y la libertad se repliega, porque suele ser siempre una verdad que molesta. El arte se hace entonces colaboracionista, lo que sorprende y mucho, porque se pensaba que el arte era una bandera revolucionaria a perpetuidad. Una utopía que los propios hechos del arte desmentian (fig. 8)

La única necesariedad es la de seguir invirtiendo en la posesión de los bienes de producción. Mientras, la política burguesa que duda en el poder entre ser liberal-represiva o demócrata-carcelaria, precisa de iconos consumistas, entre ellos el paisaje, pero un paisaje que no perturbe, que no incomode la serenidad de las oligarquias elegantes a las que guía y estimula.

El cubismo fragmentará el espacio estético, estableciendo una nueva codificación de la sensibilidad. La pasión permanece, pero se invierte su perspectiva: la anarquía de su exhibición es, precisamente, la técnica que hace subyugante esa energía y la convierte en poder cultural.

El estadounidense Lyonel Feininger (1871-1956), utilizó la mecánica cubista para representar una course de veleros en 1929. Las formas huidizas de estos rápidos cruceros de placer favorecían el diseño de audaces triángulos, que se superponían a un celaje igualmente sometido a rítmicos cortes angulares. El agua participaba de esta edificación poligonal de la fantasía que posee, empero, tantos factores de identificación con la realidad marítima. El movimiento alcanza densas categorias de lo subjetivo y el tiempo parece que se fragmenta. Pero uno y otro forman idénticas constantes.

Ibidem, pág. 453. 

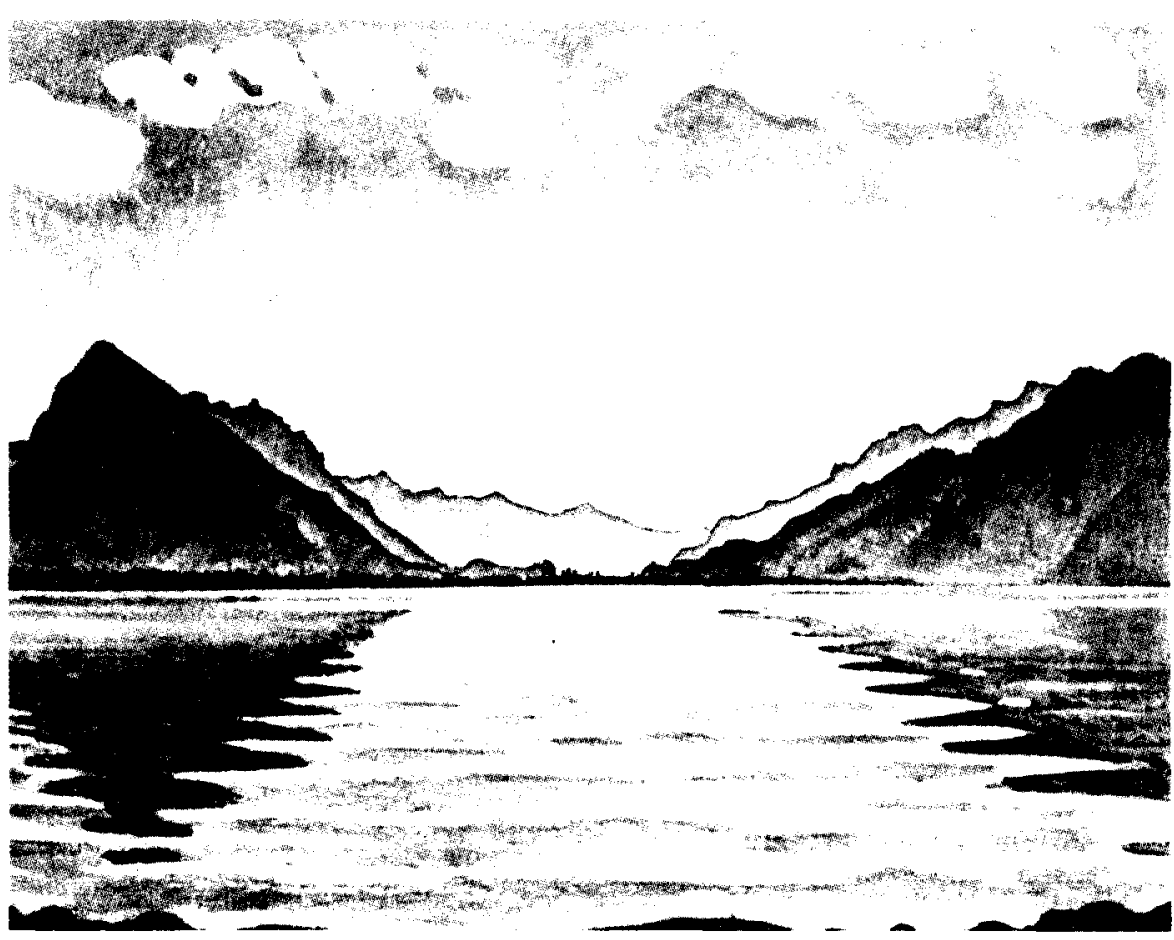

Fig. 8. "El lago Thum". Ferdinand Hodler (1905).

\section{FASCINACIÓN POR LA LINEA DE HORIZONTE}

El mar, es decir, el agua en su máxima capacidad exponencial, es el medio en el que domina una realidad y una quimera: la línea de horizonte. Es éste un mundo vigoroso y equívoco en la delimitación de esa fuerza, puesto que sus límites siempre varían, con ser éstos una histórica «permanencia". Esa línea de mar y distancia, de maximalidad e inaccesibilidad, es el tiempo.

El arte se ha sentido regularmente fascinado por la línea de horizonte, un desafío plástico de nuestra obligatoriedad conductiva, que tiende hacia objetivos especificos y evanescentes. Esa figura identifica también con la idea de inmortalidad.

El mar, la mar, son definiciones humanizadas: sin nuestra emoción carecerian de sentido artístico o estratégico, y se convertirían en inmensos depósitos de la vida meramente biológica. El hombre siente (cree) que 
domina estas vastedades de lo relativo y lo posible, y eso le hace "presentir" su perennidad como especie frente a estas panorámicas donde lo excepcional es una rutina. Pero no es así, y ese conocimiento es sólo el acceso a un nivel alejado de lo vacuo, pero no de lo inseguro, y es éste uno de los "niveles" desconcertantes del tiempo.

\section{NUEVAS TÉCNICAS PARA PLASMAR ETERNOS IDEALES}

La fotografía padeció muy pronto un encantamiento ante el agua como concepto estético, y Daguerre utilizó esa referencia en 1839 para uno de sus primeros daguerrotipos: una panorámica sobre el Sena en el que se reflejaba el depurado goticismo de las torres gemelas de Notre Dame. El espiritu de renovación luisfelipista se asomaba a la historia desde una perspectiva ecuánime, sosegada, la visión de una ciudad "intacta" a través del tiempo y de las mutaciones societales.

Gustave Le Gray (1820-1882), pintor forjado en el estudio de Paul Delaroche (1797-1856), cenáculo donde convivieron otros genios de la "primera hora" fotográfica (Charles Nègre, Henry Le Seq), comprendió rápidamente las posibilidades revolucionarias del agua en su tratamiento por un método no menos insurrecional como era la fotografía. Consumado paisajista, Le Gray es un artista que no sólo sabe componer, sino que aporta dosis equilibradoras de vehemencia y prudencia en sus originales, es decir, que sus compromisos no vulneran los modales académicos al uso.

Le Gray sabía perfectamente que el medio en sí.que utilizaba, la fotografía, ya era algo bastante sedicioso como para realizar atrevimientos adicionales. Estimó, en consecuencia, que esas acciones no serian entendidas ni tendrían utilidad para él (reconocimiento artístico y social del autor).

Por lo tanto, Le Gray, poseedor de una técnica depurada - y en magníficas relaciones con un gran investigador, el químico Alphonse-Louis Poitevin (1819-1882) - va a empeñarse en "dominar» el mar. Asunto nada sencillo, incluso hoy con los aportes de los nuevos materiales, y que entonces parecía metafísica incomprensible. En efecto, la diferencia de sensibilidad entre la superficie del mar y el cielo convertían al conjunto fotografiado en un choque de intereses particularmente despiadado. EI resultado solía ser una masa oscura (el agua), aplastada por otra masa "desnuda" (el cielo), al que la sobreexposición despojaba de toda calidad gradual.

Imaginativo y práctico, Le Gray, que trabajaba con el proceso al co- 


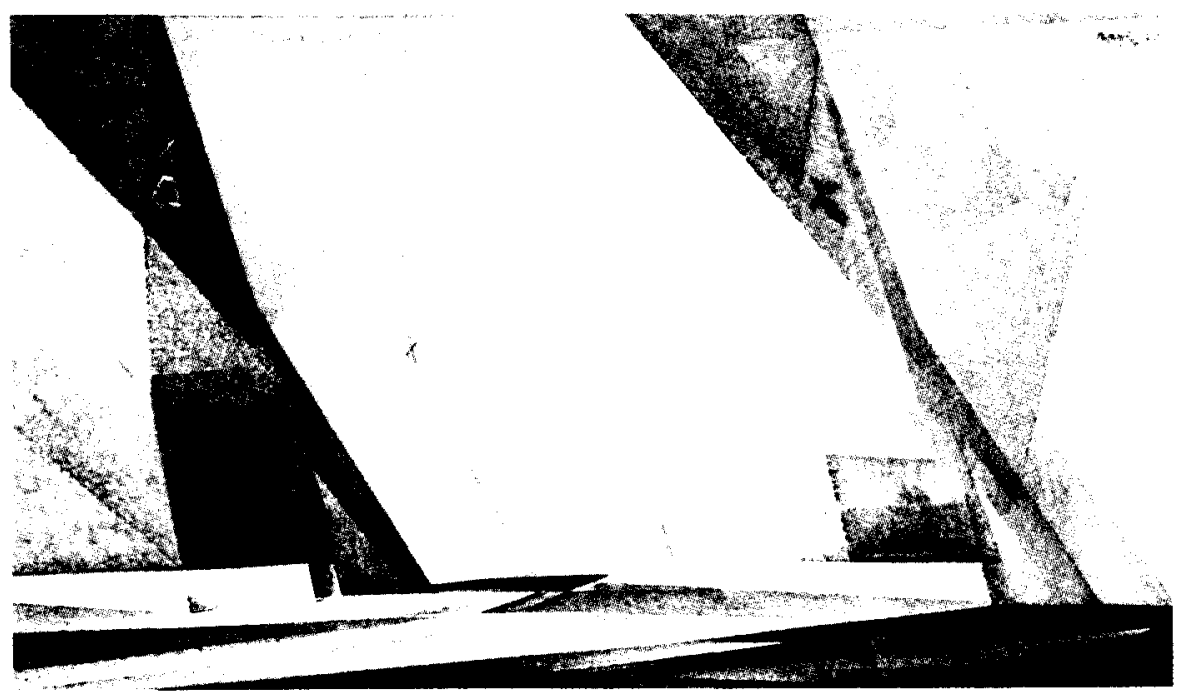

Fig. 9. "Veleros". Lyonel Ferninger (1929)

lodión húmedo - de elevada sensibilidad para la época, con exposiciones que podian oscilar entre uno y dos segundos, hasta los 8-10 segundos-tuvo la habilidad de realizar dos negativos: uno para los celajes y otro para la superficie marina, técnica que trasladaría igualmente al ámbito terrestre (caminos arbolados con perspectiva final en cielos abiertos). La intuición pictórica de Le Gray le permitió entender, acertadamente, que mar y tierra son, en su densidad fotográfica, "una misma cosa".

La conclusión era un compuesto bien equilibrado, con la valoración que correspondía a las gradaciones de grises, sin que se perdiera pujanza en las luces altas o en los atrevidos efectos de contraluz. Casi un siglo después, la misma técnica sería utilizada por José Ortiz-Echagüe (18861980) en la consecución de sus batallas pictofotográficas entre nubes sarracenas y castillos de Reconquista.

Las marinas de Le Gray son hermosas oraciones plásticas a la idea de infinitud. La línea de horizonte es en ellas un valor inmutable, una dimensión ecuménica que no admite discusión. La grandiosidad de la paz es inherente a este respecto por lo esencial del marco maritimo: la definición de las distancias y la imposibilidad de poseerlas (fig. 10).

Le Gray consigue aproximarnos al colosalismo de la naturaleza, pero como trata el asunto con exquisitez -en realidad, sus fotografías son, virtualmente, "pinturas de época", pues no rompen los cánones compo- 


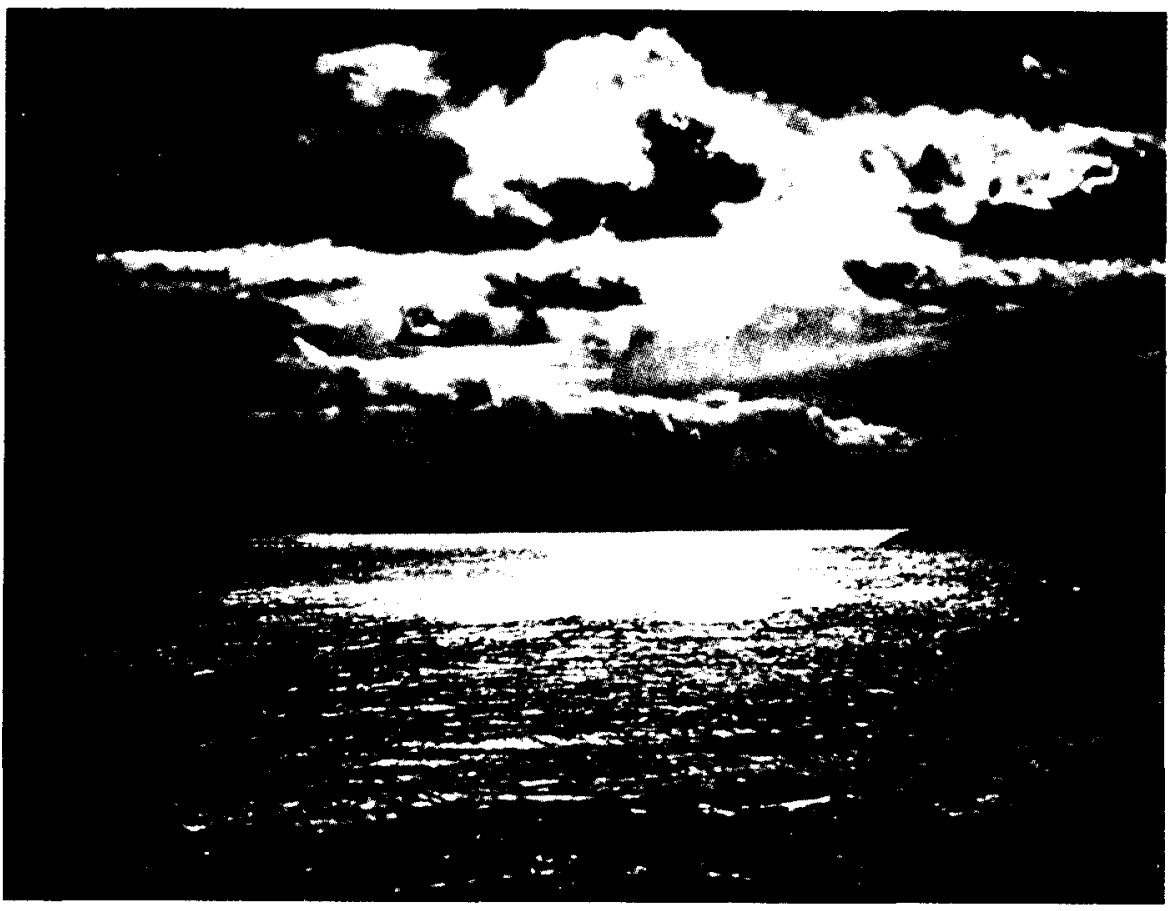

Fig. 10. "Marina». Gustave Le Gray (1857)

sitivos establecidos - su contemplación nunca fue perturbadora, excepto en el nivel de la competitividad artística con la pintura, inquieta en grado sumo ante esta "ofensiva" de sensibilidad y realismo simultáneos.

Pese a ello, su primera colección de marinas fue rechazada, y Le Gray tuvo que sufrir la mortificación de una crítica que negaba su calidad por ser sus obras "producto más de la ciencia que del arte», según reseñó en su momento La Lumière, órgano de la Sociedad Heliográfica en $1850^{5}$. Pero el triunfo llegaría con carácter de inevitabilidad, y en 1856 Le Gray obtenía la Medalla de Primera Clase en la Exposición Universal, para luego convertirse en uno de los fotógrafos favoritos de Napoleón III. El II Imperio, una idea de política inmortal. En cuanto a Le Gray, fallecería en El Cairo,

COE, Brian, Allison, David y otros, Técnicas de los grandes fotógrafos. Traducción de Alfredo Cruz Herce sobre la primera edición en inglés de 1981. Madrid 1983, Hermann Blume Edicines, 191 páginas, vid. pág. 32. 
en la más completa miseria, tras haber dilapidado una gran fortuna y desarrollar una oscura labor como profesor de dibujo en la corte egipcia.

\section{LA LABOR INIGUALABLE DEL ESPEJO}

El agua es la vida, pero también la conciencia. $Y$ eso es asi porque una de sus esencialidades es la de mostrarnos el mundo dividido, es decir, lo que es verdad y lo que no parece serlo. Es el poder del reflejo, la fuerza de la imaginación que se debate entre el sí y el no.

¿Qué somos, lo que parecemos ser o lo que el espejo no puede reflejar, que es nuestra «imagen interior»? Esa tensión va a acompañarnos perpetuamente hasta el fin de nuestra presencia en la historia que nos tocó vivir. Ser "Sólo en parte" (la totalidad del reflejo pertenece a la física), es una de las limitaciones del hombre ante su siempre crítica sinceridad individual y colectiva en el escenario que le dibuja el tiempo. Aparece así "el hombre incompleto", aquél que continuamente se repliega ante la proximidad intimidante de la verdad absoluta. Algo ciertamente lógico, pues si el hombre no temiese a la verdad dificílmente podría ser hombre.

La verdad absoluta no está hecha para el hombre, sino para un ideal, una potencia indefinible. $Y$ aunque esa categoría pretenda pasarse por el cedazo de "lo humanitario", la directriz es, en sí misma, "antihumana", porque el ideal nunca se consigue percibir en su totalidad. Igual que el mar, la tierra o el cielo. Por eso el ideal humanizado es el inconcluso, lo que le hace "perfecto". Además, si el hombre quiere seguir siendo considerado como tal, esto es, dotado de capacidad de asombro (lo que certifica su conexión con la humanidad), no podría soportar la revelación instantánea de la verdad en toda su dimensión material o espiritual, esa inserción con lo temerosamente descubierto, ya fuese lo hermoso o lo aterrador.

En el arte, la función del espejo conlleva angustias psíquicas evidentes, y el agua es la lámina ideal que reproduce cuántas dobles verdades o mentiras se quieran, y esto sin comprometer al autor ni a los testigos de esa acción. La fotografía ha hecho de la utilización del agua-espejo una de sus aficiones más intensas, consciente de la inagresividad del proceso.

El pictorialismo novecentista fue la tendencia que, con más ahínco, creyó firmemente en los valores del espejo. Reflejar árboles, casas, puentes, cielos y, en menor medida, personas (sintoma infalible de vacilación o de pánico hacia el espejo), fueron casi una uniformidad en "los años dulces" de este género (entre 1880 y 1920). 
El británico George Davidson (1854-1900), típico representante del pictorialismo en la Inglaterra victoriana, utilizaba ya escenarios de reflejo donde el efecto de "velo" (de hechizo), de por si era muy acusado en su originalidad geofísica: márgenes de ríos silentes, estanques aislados y mistéricos, acantilados solitarios, cielos majestuosos pero también dotados de un aura de "penitencia» estética.

En 1898, cuando Davidson era presidente de la Kodak Ltd. de Gran Bretaña, fotografió un estanque en Weston Green, al que positivó luego por medio de la técnica de fotograbado a la goma, un nuevo efecto de velado (tramado), que repetía o incentivaba ese mecanismo sonador del flou, la obsesión de la fotografía romántica por desfigurar la realidad (fig. 11).

Los árboles transmiten una imagen de sueño, porque el fotógrafo pictorialista pasaba su existencia en plena somnolencia histórica: cuando apuntaban con fuerza los modos del futurismo en la pintura, y las formas del cubismo estaban próximas a aflorar, la fotografía vivia sumida, en su mayoría conceptual, en una especie de éxtasis ruskiniano, en pos de un retorno de Cruzada hacia los mundos imposibles. Frente al industrialismo de la sociedad y del arte, se trataba de alcanzar el equilibrio entre Hombre/ Dios/Naturaleza por medio de un talante goticista o simplemente manierista. $Y$ todo esto mientras la capacidad tectónica de los militarismos imperiales y las imperialidades dinásticas acometían su delirio autodestructor más notable.

Los árboles de Davidson muestran un paisaje embrujado, por tanto, un irrealismo muy al gusto de la insensibilidad geopolítica y socioburguesa del momento. El pictorialismo, el ocultamiento de "la verdad sencilia", es la religión de la época, tanto fotográfica como política. Lo que se pretende es el mayor de los imposibles: hacer retroceder el tiempo. En realidad, se trata de un tardorromanticismo fotográfico con algunas sacudidas neoimpresionistas (Emile Puyo, Clarence Hudson White), que tardará en morir, aunque la Gran Depresión, con su realismo cruel, lo lleve inmediatamente a un fúnebre nicho del olvido. El romanticismo, ya sea fotográfico o simplemente político, nunca está hecho para encarar las quiebras bancarias o climatológicas - por los años de sequia que azotaron la Norteamérica en bancarrota entre 1930 y $1934-$.

Los hermanos Oskar (1871-1937) y Theodor Hofmeister (1868-1943), hicieron de su ciudad natal, Hamburgo, uno de los focos emisores del pictorialismo europeo. Grandes exponentes del proceso a la goma bicromatada - técnica a la que aportaron sucesivas mejoras, y que usó asi mismo, con maestría inigualable, Ortiz-Echagüe -, se empeñaron al unísono en una guerra de gran predicamento estético: reconvertir la fotografía, es decir, lograr su elevación hacia la cúspide del arte a través de 


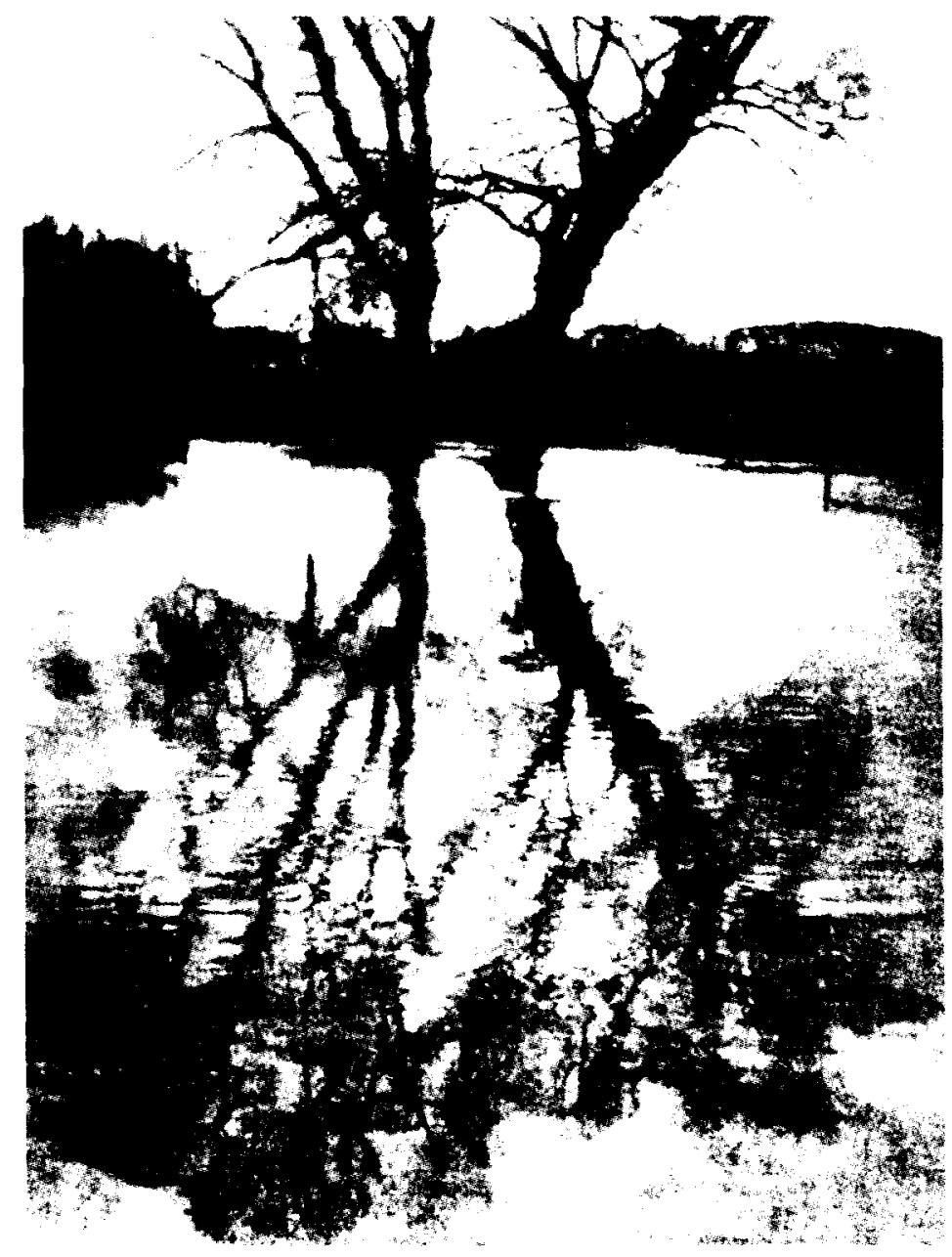

Fig. 11. "Arboles en el estanque". George Davidson (1898)

su identificación (copismo) de los encuadres pictóricos, una tesis en la que los guerreros fotográficos a los Hofmeister fueron auténtica legión. Estas dudas conceptuales revelaban una "maia conciencia» en la fotografía, lo que no tenia sentido, pero que en aquel momento asfixiaba su independencia creativa y ejercía, por ende, una profunda negatividad sobre su valor cultural.

De uno de los encuadres de los hermanos Hofmeister en 1904, una 
iglesia rural, se deducen mejor las virtudes del espejo. Se trata de dos mundos que, al ensamblarse, recomponen el ritmo de su expresividad formal. La iglesia campestre, en su parca soledad y en la panorámica deshabitada que la rodea, no nos dice mucho. Pero debajo de ella transcurre su otro yo, esa segunda línea de horizonte, que es la que nos conduce hacia la ribera de lo variable, lo reflexivo.

El autoritarismo erguido de la iglesia «legítima» en si mismo ni es ejemplar ni es potencia estética, pero su reflejo rompe la vulgaridad por la vía dialéctica de los contrarios, que imponen una idea de movilidad, de trascendencia, lo que explica el recorrido del tiempo y edifica una nueva señal de su antigua verdad. De esta forma, resulta ser más verdadera la iglesia que "no es", la reflejada, que la que origina el reflejo con su testimonio de inamovilidad, de inexpresividad, y a la que dota de una nueva autoridad moral (fig. 12).

El espejo es como el eco, la reverberación de las ideas, que a menudo son mucho más importantes (más explícitas) que la base motora que las produjo. El espejo es la simbolización de los gemelos (tesis y antítesis). La sintesis la pondrá el tiempo. El fotógrafo se limita a testificar su respeto a lo que está sucediendo, resalta la situación de la que es testigo y reproductor estético a la vez. No va más allá. No pretende atribuirse su

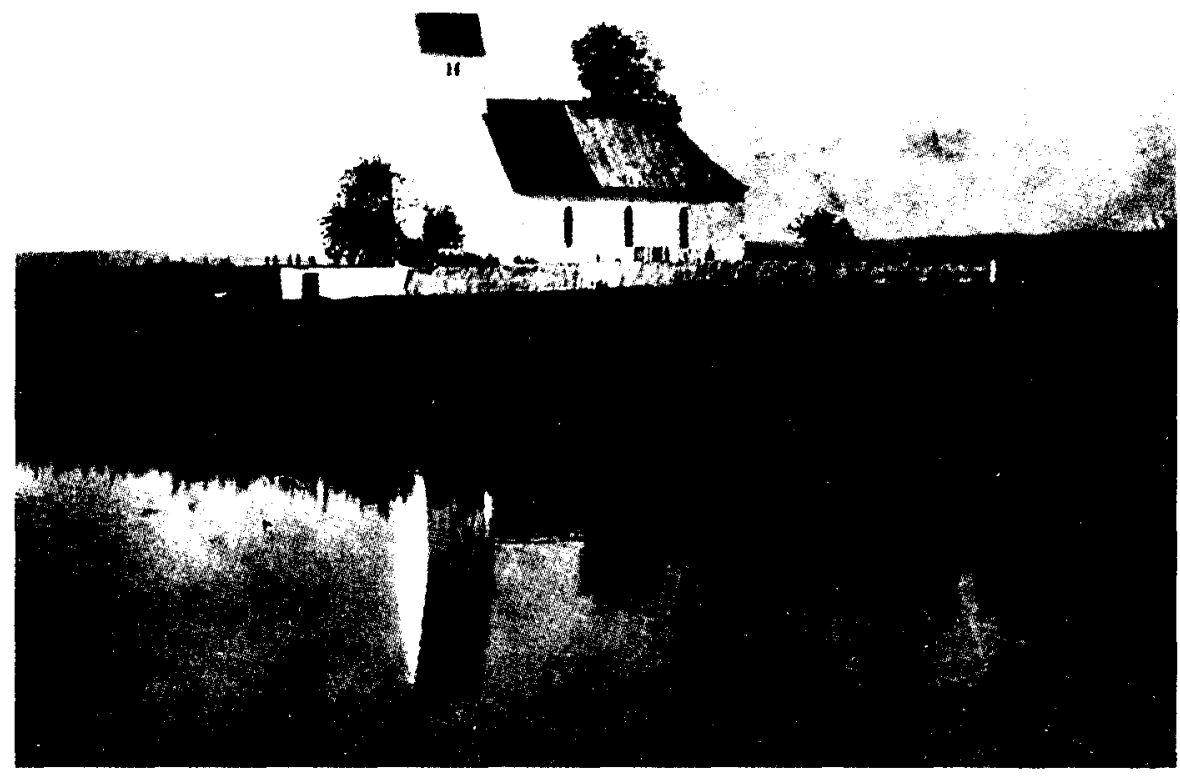

Fig. 12. "Plano acuático con iglesia». Oskar y Theodor Hofmeister (1904). 
patrimonialidad. Sencillamente la descubre y luego la exhibe, pero no la modifica en sujeto de posesión.

En la simbología china, se habla de “los animales en los espejos», es decir, las inestabilidades y amenazas del otro yo. Por eso los espejos pictorialistas no son contactos directos con la señal de la verdad. Prefieren efectuar un paseo por su reminiscencia, el recuerdo de cómo pensaron que "debía ser» esa verdad.

\section{VIVIR Y COMBATIR EN EL AGUA}

La flexibilidad del agua en su uso por el hombre adquiere pasmosas ductilidades. Símbolo de abismo, de riesgo y de aniquilación, es, sincrónicamente, símil de emergencia hacia la vida que se creía perdida, por lo tanto, es valor de resurrección. Su aplicación va desde la facultad de lograr el reequilibrio metabólico (la tensión de la sed, la idea de agotamiento que desaparece), a la aptitud para actuar como refugio del hombre frente a otros hombres (idea de islote, de salvaguarda frente a las guerras o las insensibilidades).

La fotografía nacionalsocialista exaltó las virtudes del "hombre nuevo", ese espíritu nietzscheano que dominaría el mundo desde su no-cansancio, su no-sensibilidad, su no-tolerancia. Aquella gran comuna de humanidad tecnoacorazada que fue el III Reich no se permitia vacilaciones ni siquiera con la necesidad de beber agua (imagen de pausa, de meditación). Pero Lotte Zangemeister (act. años treinta), decidió, en 1938, hacer una excepción a la regla: si "el hombre automático" no podía beber, paréntesis insoportable para un ser mecánico, concebido para la batalla, al menos que la adolescencia bebiese. Tiempo habria para morir, antecedente de la perspectiva remarqueniana.

La audaz composición en diagonal de Zangemeister expone dificultades y factibilidades de acceso a un elemento vital. El árbol, materialidad cómplice de la acción, es el puente por el que se llega al agua pura, la que está inmersa en la corriente de la historia, la no estancada. Madera, líquido y pubertad son tres valores confluyentes. El muchacho no añora la niñez, su autonomía física le permite ser tan atrevido como para recorrer un espacio circunstancial (el tronco abatido), y saciar su curiosidad en la eventualidad de un reposo de "la vigilancia general» (fig. 13).

Este joven intrépido no es un espécimen de las Juventudes Hitlerianas: ni lleva uniforme ni está pulcramente aseado, es un pedazo desprendido de la norma social vigente. Una emancipación cultural insólita. El adoles- 


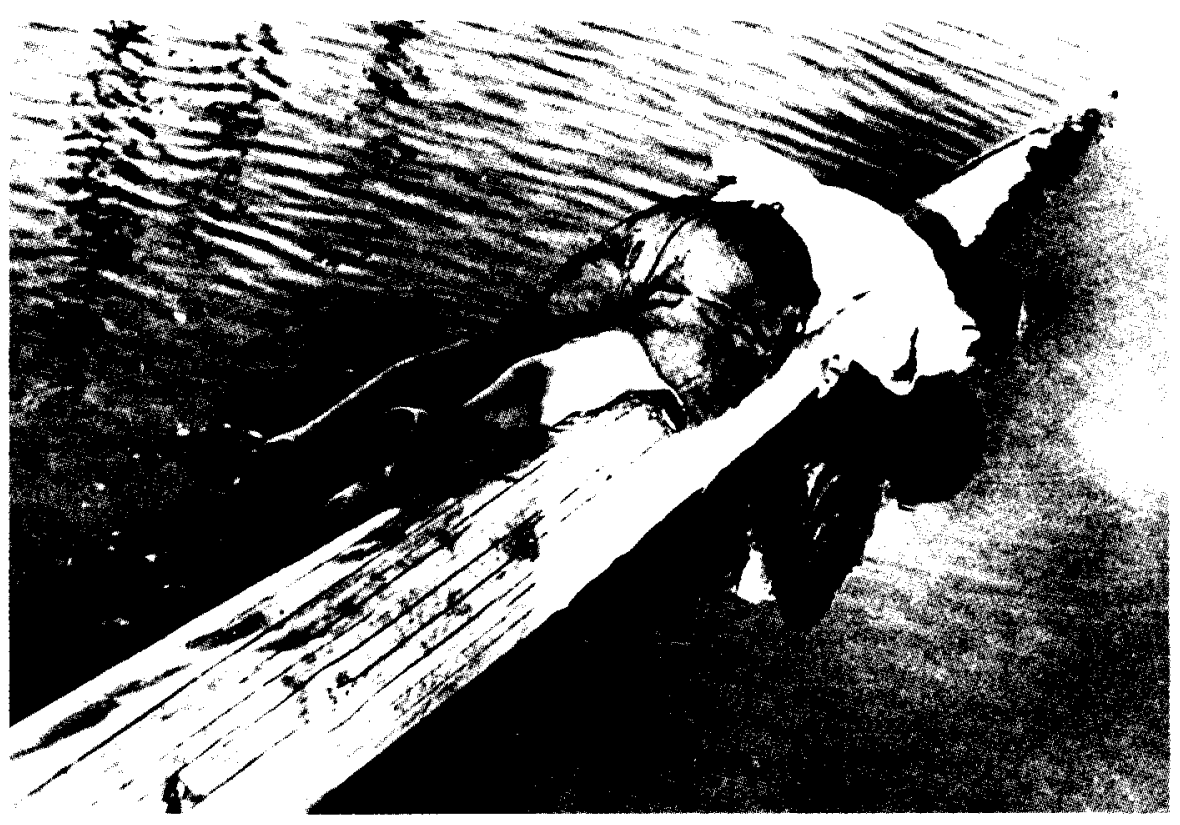

Fig. 13. "Chico bebiendo el agua de un rio". Lotte Zangemeister (1938).

cente bebe directamente del futuro. Su reflejo le observa a su vez con una mezcla de admiración y de preocupación.

Ese niño es ya un "superhombre": ha sido tan osado como para no beber en las fuentes señaladas por las instituciones (las paternas o las gubernamentales). Es un rebelde, que bebe de la audacia, del reconocimiento de saberse dueño en ese único instante de sus actos. Y es libre, porque al hacerlo así no se opone a la coherencia de todo proyecto juvenil, iconoclasta de las formas. Bebe del tiempo, sintesis de lo inaprehensible y lo imprescriptible. Este joven ejerce la automanumisión, la doble ruptura de las ligaduras generacionales e ideológicas. Puede que no sobreviva a la guerra inminente, pero otros como él beberán también de “las aguas independientes» y recibirán la caricia de la razón en la paz que viene.

\section{DESEMBARCOS EN LAS SORPRESAS DE LA IRA}

Decía Lao-Tsé que «el agua no se para ni de día ni de noche. Si circula por la altura, origina la lluvia. Si circula por lo bajo, forma los ríos. El 
agua sobresale en hacer el bien». Pero el agua participa también de las turbulencias de la historia, esas modificaciones brutales que el hombre desarrolla en su periferia consciente, porque la centralidad del agua, como la de la tierra, deberian conducirle hacia la paz, lo que en modo alguno es asi.

En la proclamación de las furias insensatas de la Segunda Guerra Mundial, el agua era un martirio, cementerio abisal en el que se hundian mercantes, acorazados, portaaviones, submarinos, voluntades, órdenes, soberbias y esperanzas. Pero de vez en cuando el agua mostraba ese carácter sublime suyo de ecuanimidad, esa capacidad no sólo de fosa, sino de albergue que acoge al hombre desamparado. En la playa de Omaha, sintesis funeraria de las divisiones norteamericanas desembarcadas para la liberación de Europa, Robert Capa (1913-1954) se introdujo en la vorágine del terrible suceso - hubo más de mil muertos estadounidenses en menos de tres horas - para explicar cómo el agua puede salvar a un soldado, al hombre.

En la imagen de Capa, el sentido taoísta de movimiento continuo del agua es absolutista confirmación. El soldado es un material a la deriva, inmerso en un torrente que no parece consentir otro matiz que el de la exterminación inmediata o inevitable. Junto a su desconcierto, fusilado desde todos los ángulos posibles, se mueven los obstáculos antidesembarco - las famosas estacas triangulares que diseñara Rommel-; los restos de vehículos y de otros hombres; el golpeteo de las explosiones y los gritos incomprensibles; la inenarrable confusión que producen el miedo y la derrota.

Un colectivo de hombres lucha tenazmente para que otros formen una parte instantánea de los muertos. Se mata y se defiende la vida en una común desesperación. La prisa por "no saber» (separación de la conciencia) es común agonía.

Esta imagen clásica de la guerra se ha entendido regularmente como una testificación abrumadora de las bestialidades tecnológicas que el hombre ha impuesto en nuestra modernidad a sus semejantes. Nada de qué asustarse. La barbarie y la cólera seguían siendo las mismas en la Normandía de Capa que en la Crimea de Fenton. Sólo las diferenciaba el hecho de que Fenton trasladó el pánico a una visión intimista, "reflejada" de la guerra - lo que pudo suceder antes de su celebérrima imagen del Valle de la Muerte, en Balaklava--, mientras que el fotógrafo checonorteamericano ha introducido al soldado en la trituradora de los implacables realismos: máquinas y elementos parecen dispuestos a acabar con toda vida humana. Si no cae fulminado por la metralla, el agua rematará a ese hombre. 
Cierto es que muchos "marines" murieron ahogados, arrastrados al fondo por el peso de sus equipos de campana. Pero eso fue por causa de la inconsciencia de quienes les lanzaron al ataque lejos de la línea de playa. Empero, en la fotografía de Capa, el soldado no lucha contra el agua, sino que la utiliza como un escudo. Desea fundirse totalmente con ella, pasar desapercibido bajo ese tumulto de la ira que se abate sobre él y sus camaradas en injusta expiación. El agua le arrastra, le macera y le aturde, pero en ese nivel conductor no le inquieta. Como un canto rodado de la batalla moderna, el soldado recorre el perímetro de la caótica realidad, pugnando por sobrevivir a esas totalidades asesinas. El agua no ha aportado ningún furor, ningún "desorden" a la escena, sino que su propia versatilidad ha evitado que muchos de los condenados a la muerte se salven bajo sus rítmicas oleadas, una maleza de formas que confunde a los tiradores enemigos (fig. 14).

El soldado de Capa hubiera deseado sumergirse en las aguas normandas y no salir "en años". La inmersión en ese elemento significaba el retorno a lo preestablecido, lo preformal, la disolución, pero también la idea de renacimiento y de concentración resucitada de los esfuerzos vitalistas emergentes. Las aguas de Omaha dieron breves pero suficientes alientos a toda una generación de combatientes abandonados por la tác-

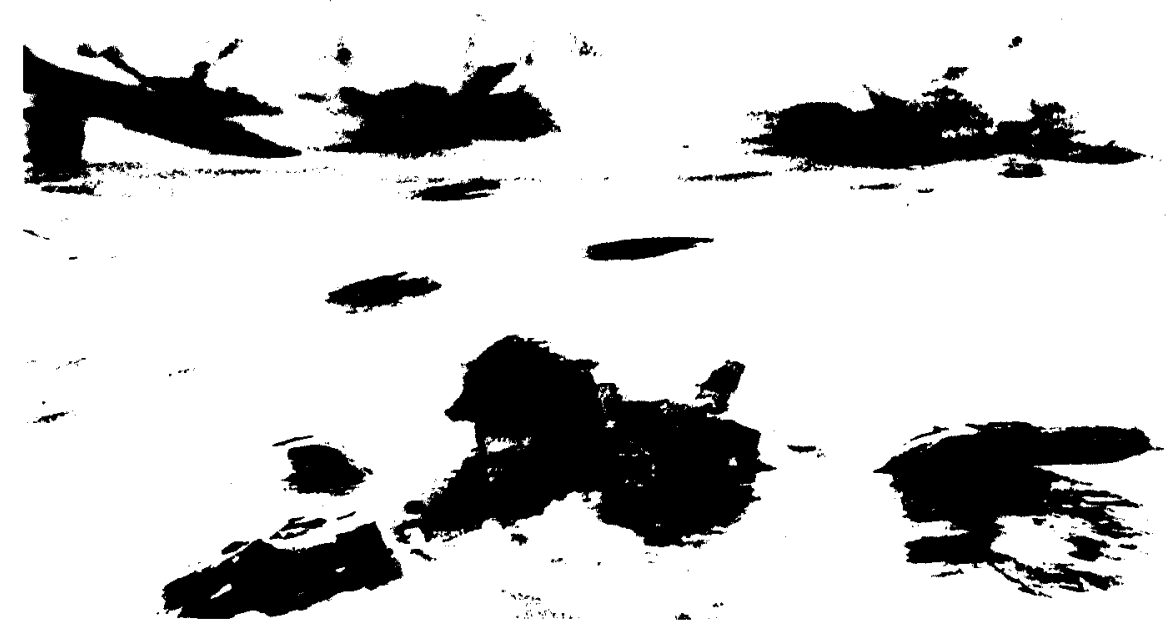

Fig. 14. «D-Day». Robert Capa (1944). 
tica, hombres que no sabian muy bien por qué y contra quienes combatían, excepto las generalidades de luchar por la libertad y, claro está, por «la salvación del mundo". Un mensaje que se repetía al otro lado, para guiar a aquellos que les apuntaban con voluntad de muerte ordenada.

El agua normanda salvó a unos y descubrió a otros la felonía de los sacrificios estratégicos. Gracias a ella, el nivel de lo razonable no fue definitivamente rematado para muchos hombres aquel 6 de junio de 1944 . No permitió inmersiones permanentes en su interior, sino tan sólo "pequeños respiros" de discernimiento entre enormes angustias y devastaciones incontrolables. Esas pausas salvaron muchas vidas. $Y$ de esas diferencias entre "no ser nada y ser algo", un perdón con el que no se contaba, algunos de aquellos soldados vieron prolongadas sus trayectorias personales de vida, una prórroga necesaria para poder asimilar el valor del tiempo.

\section{LEVEDAD DEL HOMBRE, SOLIDEZ DE LA IMAGEN}

El agua es transparente en sus actos. Incluso la más furiosa de sus tormentas responde a una lógica, a una cíclica conmoción de su energía congénita. Pero sus acciones no van dirigidas "contra nadie", no especifican el castigo, no persiguen una ejemplaridad dolosa en alguien o algo concreto. El agua, como el tiempo en su versión humanizada, se limita a exponer una inmutabilidad, que sólo será asimilable mientras ambos factores se relacionen por la vía de la inteligencia, agotada la cual, la primera desaparecerá, y sólo quedará la absoluta aridez del segundo, suspendido en la indiferencia cósmica.

A veces, la superficie del agua provoca inmensas catástrofes, y en otras ocasiones su inalterabilidad se entiende como una incitación al pacifismo. Poetas y literatos, pintores o fotógrafos, artistas reproductores del instante bárbaro o tranquilo de las aguas conceptuales que cada dinámica cultural formó, aprovecharon esas visiones para interpretarlas como proyecto de futuro.

El norteamericano Irving Penn (n. 1917) fue un consumado retratista de la sociedad posthuxleyeana originada tras el segundo conflicto mundial, particularmente con sus fotografías de moda. No obstante, a veces supo apartarse de esa inercialidad donde la fama es sólo producto de temporada, y permitía que su atención reflejase las tensiones eternas a través de una sencilla imagen de paseo fluvial.

El hombre de Penn que navega plácidamente sobre el Sena, en 1951 , 

esta imagen donde la armonía muestra límites aparentemente consolidados, y en la que todos los actores presentes o latentes parecen dispuestos a no provocar ninguna ruptura violenta. Pero esa felicidad es efímera, y lo que nos advierte el original de Penn es de la necesidad de no desaprovechar todo aquel intervalo de concordia que nos sea dado.

Las fuerzas, ya sean humanas o geológicas, han impuesto una tregua. El agua, tratada por el pictoricismo de Penn, se ha evaporado, una inmaterialidad que, pese a ello, no intranquiliza. Sin embargo, es perceptible su comparecencia en este cuadro de lo históricamente razonable. Al «no ser» únicamente en su visualización artística, el agua se procura una nueva dimensión, se convierte en una abstracción de nuestra relatividad consciente. $Y$ es que ella es también el tiempo, el que más necesitamos y el único que puede volver, porque nosotros "somos" el agua, y sin ella volveremos a la nada. 
